\title{
1. SOURCES OF INFORMATION
}

\section{A. General bibliographies.}

In his pioneer article entitled El rol de la antropología social dentro de las ciencias sociales en España, published in 1971 (cf. Kenny. Ethnica, 1: 93-105), Michael Kenny is concerned with presenting a first bibliographical review of studies conducted up to the 1970 s by rural sociologists, economists, human geographers, social psychologists and, of course, anthropologists. Kenny singles out some of the major topics of general research, as well as the fieldwork on specific subjects carried out by a total of about forty foreign ethnologists, mostly North Americans. M. Kenny defines his own aim as being to establish the state of the art with a view to generating more complete information on which to plan future research.

The second general approach is signed by Isidoro Moreno and entitled La investigación antropológica en España (cf. Moreno, 1975. In: Primera Reunión de Antropólogos Españoles, pp. 325-338). In the first part of his article, Moreno undertakes a critical reflection on the context in which recent Spanish anthropology has developed, pointing out the numerous academic, political and ideological hindrances that existed. Against this rather discouraging background, the author dedicates the second part of his article to presenting the broad trends that have emerged in collective research and to reviewing individual research projects already completed or in progress, classified by geographical area.

While Moreno's work concentrates strictly on anthropological research proper, the Bibliografía de Antropólogos Españoles drawn up by Alfredo Jiménez and Elías Zamora for inclusion in the proceedings of the Primera Reunión de Antropólogos Españoles (cf.Ibid. 1975 pp. 363-395), is not confined to the works of cultural and social anthropologists, but covers the output of certain physical anthropologists, paleontologists, prehistorians, archeologists and historians and ethnohistorians of America ${ }^{12}$. As the bibliographers point out, this work is based on information sent by the authors themselves to the organizing committee of the first Congress of Anthropology held in Seville in the spring of 1973 . There are a total of 871 entries. This bibliography of Hispanic authors is followed by another entitled Bibliografía de antropólogos extranjeros sobre España (Ibid. pp. 379-401), in which more rigorous criteria were applied, since it comprises only eighty-six titles by cultural and social anthropologists.

The fourth bibliography, Una aproximación a la bibliografia antropológica sobre España (cf. Prat 1977. Ethnica, 13; 130-173), is a compendium of the 
information contributed by the preceding works. The 513 entries are assigned to six sections without headings but based on type of publication: a) sources of information in the broadest sense; $b$ ) historical surveys of Spanish anthropology since the 19th century; c) monographically oriented studies; d) research on particular geographical areas, particularly those carried out in rural contexts; e) urban anthropological research; and f) classification of studies by subjects. At the end is a hand-calculated statistical appendix.

The last general bibliographical work of this type known to us is by Joan Prat and Joan Josep Pujadas and entitled Spanish Anthropology: A Selected Bibliography (I and II) (cf. Prat/Pujadas 1981) and was prepared at the request of the Society for Spanish and Portuguese Historical Studies. The bibliographical materials were grouped together under the following headings: 0) Some Spanish Journals; 1) Bibliographies. Evaluations and Perspectives on Spanish Anthropology; 2) Change in Rural Society; 3) Community Studies; 4) Comparative Studies and Collective Works; 5) Social Stratification and Local Power; 6) Social and Economic Structures; 7) Urban Studies; 8) Migration; 9) Ethnic Minorities. The work comprises a total of 370 references.

In addition to the general surveys we have just listed, there are of course other more marginal but nonetheless useful sources of information. The first is the work already mentioned by Susan Tax Freeman and Laura R. Walters, Europeanist Social Anthropology in North America. A Directory (1975), which contains several reviews of the work of North American Hispanist anthropologists. Another work of the same type which is well worth consulting is by Juan Diez Nicolás, Juan del Pino Artacho and Rafael Gobernado Arribas and bears the title Cincuenta años de Sociologia en España.Bibliografía de Sociología en Lengua Castellana (Universidad de Málaga. 1984). It includes 4320 general sociological references, some of which are directly relevant to our field of study ${ }^{13}$.

The authors of all the general bibliographies we have commented upon followed the same chronological criterion that we ourselves adopted: their lists include nothing but anthropological works about post-Civil War Spain or, more precisely, from the 1950 s to the present time.

However, as we shall see later, there are clear indications of interest in the history of anthropology in Spain ${ }^{14}$ in another group of articles devoted to the analysis of certain regional and/or national traditions relating, for example, to Andalusia, the Canary Islands, the Basque Country, Catalonia and, to a lesser extent, Castile and Aragon.

\section{B. Partial bibliographies}

The first work published in this new line of research was La Antropología en Andalucia. Desarrollo bistórico y estado actual de las investigaciones by 
Isidoro Moreno (1971), which consists of a systematic review of past and present trends in Andalusian anthropology.

The author is concerned in the opening section with describing the historical development of the anthropological sciences in Andalusia ${ }^{15}$. He then undertakes a systematic presentation of studies of Andalusia conducted by cultural and social anthropologists. Moreno, who provides a mainly chronological account, deals with the authors, the places where their research was conducted, and their subject orientations and preferences. This overall view is supplemented by another section devoted to reviewing the work of human geographers, rural sociologists, economists and other academics on the "Andalusian agricultural problem". He concludes his article with a bibliographical inventory of 181 selected references.

Isidoro Moreno has repeated his analysis of this subject on a number of occasions $(1978,1979,1980,1982)$. The last article of his of which we are aware is La Antropologia Cultural en Andalucia. Estado actual y perspectivas de futuro (In: Rodríguez Becerra, 1984). The title of the Catalan version, La doble colonització de l'antropologia andalusa i perspectives de futur ("The dual colonization of Andalusian anthropology and future prospects") (cf. Moreno 1984. Quaderns de l'I.C.A. núm. 5) conveys more accurately the critical, programme-oriented tone which pervades the entire article.

Salvador Rodríguez Becerra, for his part, has written an article on the same subject entitled Estudios de etnología y folklore en Andalucía. Crónica y repertorio bibliográfico (forthcoming). In this work, he also addresses the question of the origins of Andalusian anthropology and highlights the process of institutionalization that has taken place from the $1960 \mathrm{~s}$ to the $80 \mathrm{~s}$. A brief reference to research on Andalusia by Andalusian and foreign anthropologists is complemented by an exhaustive and obviously useful bibliographical repertory comprising 587 references.

A general survey of anthropological studies conducted in the Canary Islands has been undertaken by Alberto Galván in a book soon to be published entitled Islas Canarias: Una aproximación antropológica. This work is divided into two quite distinct parts: the first is devoted to the historical development of anthropology in the area - an aspect on which brilliant research has been done by Fernando Estévez ${ }^{16}$ - while the second, entitled "En torno a la antropología cultural canaria", focuses on recent anthropological output. Galván prefaces this second part with a brief reference to the research carried out by foreign anthropologists (much of which is still unpublished), after which he concentrates on a detailed account of the major areas and problems studied by native anthropologists from the second half of the 70 s to the present time. These studies, which are oriented towards the analysis of the economy and ecology of the archipelago's peasant and fishing communities, and to more ideological aspects like ethnicity, symbolism and the history of anthropology itself, are part of a wider framework -that of a general theory of the transition of Canary Island society and culture. 
The Basque Country is the third autonomous community where general bibliographical surveys have been carried out. The authors are Jesús Azcona $(1981,1982,1984,1984,1985,1986)$ and Teresa del Valle $(1981)$ respectively. In the series of articles he has devoted to the subject ${ }^{17}$, Azcona analyzes, from an eminently historiographical perspective, the theoretical, methodological and ideological paradigms that have marked the development of Basque anthropological thought under the leadership of its founders Telesforo de Aranzado, E. Eguren and, first and foremost, José Miguel de Barandiarán. Azcona has also analyzed, often critically, the influence that these historical approaches, especially those of Barandiarán, still exert in present-day Basque ethnology. This indeed is the subject which serves as the starting point for Teresa del Valle's article Visión general de la antropología vasca, which pays more attention to current problems than does the work of Azcona.

Using the context of the crisis of ethnology in the Basque Country as her starting point, Teresa del Valle reviews certain peculiarities which are still characteristic of Basque anthropology today. These include: the predominance of research in a rural context; the emergence of a specific theoretical orientation (that of the historians of the School of Vienna); the priority given to gathering and describing data over theoretical analysis; and finally, the socio-political context, with close links to the problem of ethnicity and Basque nacionalism, in which research has developed. Teresa del Valle compares this type of research, which received direct encouragement from Barandiarán, with the work some American anthropologists have done in the Basque Country and the new research that is being carried out by some members of the Department of Cultural Anthropology at the Zorroaga Faculty of Philosophy and Education Sciences.

Catalonia ${ }^{18}$ is the fourth community to which an overall bibliographic article has been devoted -Antropologia catalana $i$ antropologia a Catalunya: tradicions i nous enfocaments by Joan Josep Pujadas and Dolors Comas d'Argemir (1982). The authors divide their work into three sections: 1) historical notes on the development of anthropology; 2) anthropological studies on Catalonia; and 3) towards a Catalan anthropology. In the first section, the most significant periods in the recent history of Catalan anthropology are outlined. These are defined as: the emergence of anthropology (1968-1974), its consolidation in the university context (1974-78) and its institutionalization (1978-82). The last period is characterized by the establishment of a series of currents in research in the university and parauniversity field.

The second section is devoted to the actual presentation and revision of the works. The authors make an assessment of anthropological studies on Catalonia in general, taking into account the theoretical models which underly the research itself. Pujadas and Comas thus establish a broad typology of methodological approaches which enables them to give a systematic 
account of the main trends in recent Catalan anthropological research topics, classified under a series of meaningful headings -works on modernization, experiments with urban anthropology, etc.

This same approach, in a much more elaborate and well-defined form, is to be found in another work by the same authors entitled Aragón y Castilla en la literatura antropológica (cf. Comas d'Argemir i Pujades, J.J. In: III Congreso de Antropología. San Sebastián. Forthcoming). In this new survey, Comas and Pujadas propose a critical reading of anthropological output on Aragon and Castile ${ }^{19}$, at the same time reviewing, by means of specific examples and authors, some of the major methodological problems connected with the selection of units of observation and analysis (Where is research done and why?), with the control (or lack of control) of the studies, and with the generalization and frequent extrapolation of the data. They also describe the interpretative context in which the various studies have been carried out (culturalism, theory of modernization, funtionalist structuralism) and the importance attributed to the time factor. Two bibliographies, one comprising fifty-five titles on Aragon and the other forty-nine on Castile, form the final part of this critical assessment, which, in our opinion, could be extended to cover practically the whole of anthropological literature about Spain.

Whereas this last article is concerned with recent anthropological output on both Aragon and Castile, a work by Angel Gari entitled Antropologia Social y Cultural (cf. Gari 1984, V Jornadas sobre el estado actual de los estudios sobre Aragón) provides considerably more historical information on Aragon alone. This work is broad in scope and sometimes, in our view, the information gathered goes beyond the boundaries of social and cultural anthropology specified in the title. In any event, under heading 4, 5 and 6 Angel Gari offers a carefully prepared overall picture of the different groups of anthropologists - whether Aragonese, Spaniards in general, or foreigners who have undertaken research or published works about Aragon.

When this introductory text was already finished, we were given the opportunity to read a book hot from the press -La Antropologia Cultural en España. Un siglo de antropologia- directed by Angel Aguirre (1986) and written in collaboration with various specialists in the history of ethnology and folklore from the various autonomous communities. This book is undoubtedly the most ambitious project yet to be undertaken and the second part, entitled Etnologia y folklore en las regiones españolas (pp. 87-394), is an important contribution to the overall picture we have been attempting to outline ${ }^{20}$.

C. Acts of congresses.

The exhaustive analysis of the general and partial bibliographies discussed above revealed the importance of a third source of general infor- 
mation: the published acts of congresses, meetings, symposiums, conferences and so on. Not only is this type of publication of obvious use as a source of primary information: it is also revealing in a more general way. Through careful study of acts one can ascertain how collective interests -whether professional, institutional or scientific- have envolved, and thus obtain an accurate picture of the ever-changing situations, past and present, that different groups of professional anthropologists have gone through. To develop this hypothesis would be a lengthy matter and this is probably not the most suitable place for doing so ${ }^{21}$. We must confine ourselves, therefore, to drawing up a preliminary list of the gatherings of which we are aware, especially those that have given rise to publications. Having done this, we will proceed to identify some of the major profiles which, in our opinion, can be inferred from materials of this type. A list of the publications arising from Congresses can also be of assistance in completing the information presented below.

In 1973 the University of Seville's Department of Anthropology and Ethnology of America organized a "First Meeting of Spanish Anthropologists" (Primera Reunión de Antropólogos Españoles), and two years later A. Jiménez Núñez (cf. Ibid 1975) published a volume of acts bearing the same title. In fact this "first meeting" in Seville was the founding congress of contemporany Spanish cultural anthropology and has been regarded as such ever since.

The meeting in Seville was such a success that a "Second Meeting of Spanish Anthropologists" (Segunda Reunión de Antropólogos Españoles) was organized in Segovia in 1974 by the Department of Anthropology and Ethnology of America of the Universidad Complutense de Madrid. Two volumes of acts prepared by Miguel Rivera (cf. Rivera (Ed.) 1977 and 1978) were issued under the titles Antropologia de España y América and Perspectivas de la Antropología Española respectively.

The first Congress proper was held in Barcelona in 1977. The Department of Cultural Anthropology was the organizing body and was responsible for the publication of the two volumes of acts (cf. Actas del I Congreso Español de Antropología. (1980)).

At Seville, Segovia and Barcelona the various branches of cultural anthropology, in the broad sense, were represented, including physical and biological anthropologists, ethnohistorians, archeologists and, of course, cultural and social anthropologists. Only the latter, however, were invited to the other two Spanish congresses that took place in Madrid in 1981 and San Sebastian in 1984. The Asociación Madrileña de Antropología was host to the Madrid congress (cf. Actas del II Congreso de Antropología, (1985)), while the San Sebastian congress was held under the auspices of the Department of Anthropology of the University of the Basque Country. The acts of the latter have not been published, but summaries of the papers have (cf. III Congreso de Antropologia, 1984). The fourth Congress is expected to take 
place in Alicante in April 1987 and to have the same orientation as the last two.

In addition to the publications generated by state-wide congresses, from 1976 onwards one finds a large number of contributions to other gatherings, conferences and symposiums which, on account of the wide variety of types represented, considerably increase the range of this source of information. The earliest of these "partial" gatherings were the upshot of individual initiatives, whereas since 1981 nearly all have originated in institutions.

Carmelo Lisón may be considered to have set this process underway. It was he who, in 1974, organized a symposiuum in Puertomarín (Lugo) (cf. Lisón, Ed. 1976. Temas de Antropología Española) which was confined to social anthropologists, in the strict sense of the term, unlike the second Reunión de Antropólogos Españoles, held at the same time in Segovia, which was also attended, as mentioned above, by various groups including physical and biological anthropologists, prehistorians, and others. One year later Lisón organized another symposium at the Valle de los Caídos (cf. Expresiones actuales de la Cultura del Pueblo, 1970). These periodical meetings of specialists devoted to the discussion of specific subjects have continued in the form of the Coloquios Hispano-Franceses held at the Casa de Velázquez in Madrid. The acts of the 1981 and 1983 editions have just been published with a prologue by $\mathrm{C}$. Lisón and D. Ozanam under the respective titles : Los Pirineos. Estudios de Antropología Social e Historia (1986) and Culturas populares.Diferencias, divergencias, conflictos (1986). The acts of the symposium on coastal areas (Espacios Litorales) were published in 1982 by the Ministry of Agriculture. Besides the Coloquios Hispano-Franceses ${ }^{22}$, which continue to be held, in the last two years (1985 and 1986) Lisón has undertaken the organization of anthropological symposiums of a similar type which are named after the place where they are held, Sigüenza Castle.

The gatherings organized by Lisón are in any case something of an exception for since the second Congreso de Antropología was held in Madrid in 1981, and the political decentralization of Spain into autonomous communities took place, institutions have mostly taken the initiative in organizing symposiums, congresses and other gatherings.

In 1981, for instance, the Institut Català d'Antropologia (ICA) held a symposium on popular culture at Saifores under the title Col-loqui sobre l'Estudi de la Cultura Popular (part of the proceedings are published in the book by Prats, Llopart and Prat, La cultura popular a Catalunya. Estudiosos i Institucions. 1982). One year later the ICA, in collaboration with the Department of Cultural Anthropology at Tarragona, organized a second monographic symposium (cf. I Jornades d'Antropologia de la Medicina, 1982, three volums). At the same time the Department of Culture of the Catalan Generalitat (autonomous government) organized a giant congress of traditional and popular culture oriented towards folklore. The gave rise to the publication of 
two volumes containing summaries of papers and one of conclusions (cf. Resum de les comunicacions presentades al Congrés de CulturaTradicional i Popular (2 vol. s/d) and Memòria del l Congrés de Cultura Tradicional $i$ Popular, 1983)*.

Undertakings similar to those just mentioned in Catalonia took place in other autonomous communities such as the Canary Islands, Galicia, Andalusia, Madrid and Castile-León. The details are as follows.

In the Canary Islands, the Instituto Canario de Etnografía y Folklore (ICEF) ${ }^{23}$, founded at Las Palmas de Gran Canaria, held an international meeting of specialists in folklore in the autumn of 1981 (cf. Resumen del Congreso Iberoamericano de Estudiosos del Folklore, 1982). The ICEF has continued to hold similar international meetings every two years but the tendency has been increasingly towards anthropology (cf. Actas del 11 Congreso Iberaamericano de Antropologia, published in 1985 but relating to the Congress held in 1983). The third edition of this congress took place in December 1985 at Gran Canaria.

In February 1982, the Museo do Pobo Galego, in collaboration with the Section of Ethnography of the Instituto de Estudos Galegos P. Sarmiento, organized the "First Conference on Anthropology of Galicia" (I Coloquio de Antropoloxia de Galicia), the proceedings of which were published in 1984 in Cuadernos do Seminario de Sargadelos. The second conference (II Coloquio de Antropoloxia), held once more at Santiago de Compostela in the spring of 1984, was devoted to the subject: "Anthropology and the crisis of traditional society". The acts of this second conference are about to appear. On the other hand, we have no news of any publication relating to the three latest gatherings, all of which took place at Santiago de Compostela: Coloquio de Etnografía Marítima (Autumn 1984 ) , I Congreso de Folklore de las comunidades y nacionalidades históricas (January 1985) and I Congreso Europeo do Horreo na Arquitectura Rural (October 1985), the last of which was strictly ethnographic in character.

Approximately one month after the first Coloquio de Antropoloxia de Galicia took place in March 1982, the Department of Culture of the Junta de Andalucía (Andalusian government) financed the "First Meeting of Anthropologists". (I Encuentro de Antropólogos) at Jerez de la Frontera under the title "La Antropología cultural de la Andalucía de Hoy". The acts (cf. Rodríguez Becerra (Ed.) 1985. La Antropología Cultural en Andalucia) were published by the Department of Anthropology and Folklore of the Instituto de Cultura Andaluza which is attached to the autonomous government. A new organization based in Seville, the Fundación Machado, has just announced that a congress of popular religious practice in Andalusia (Congreso

*An English summary of the proceedings has just been published: Hall. J, The Congress of Catalan Popular and Traditional Culture (Editorial Altafulla, Barcelona, 1985,136 p.) 
sobre religiosidad popular de Andalucia) will take place in Seville in the spring of 1987.

When discussing state-wide congresses we mentioned the role played by the Asociación Madrileña de Antropología in the organization of the second Congreso de Antropología held in Madrid in 1981. Members of this association, who had already taken an active part in the organization of the first and specially the second "Study Days on the Province of Madrid" (cf. Ibid., I and II Jornadas de Estudios sobre la Provincia de Madrid, Diputación provincial de Madrid, 1980), joined with the Asociación Castellana de Sociología in organizing the first "Conference on the social anthropology of Castile-León" (Primeras Jornadas de Antropología Social de Castilla-León), which took place in Avila in the autumn of 1982 . The acts are ready for publication.

The ever-active AMA, this time in collaboration with the Museo Nacional de Etnología, also sponsored the first "Madrid Conference on Anthropology" (Primeras Jornadas de Antropologia de Madrid) in the spring of 1985 and, in Soria in September of the same year, various centres for the study of ethnography and folklore in Castile and León held the first "Congress of Ethnology and Folklore in Castile and León" (I Congreso de Etnología y Folklore en Castilla y León), the acts of which are forthcoming.

The Basque Country, as mentioned earlier, was host to the third statewide Congress of Anthropology (1984). Some time earlier, three editions of the gathering known as "Basque Anthropology weeks" (Semanas de Antropologia Vasca) had been held. The corresponding acts were published in 1971, 1973 and 1976 respectively. Since the San Sebastian Congress, the only gathering of which we have news ${ }^{25}$ is the second "International Encounters on Traditional Culture" (II Encuentros Internacionales de Cultura Tradicional) held at Portugalete in 1986. The subject of this meeting, organized by the Sociedad Elai-Alai, was "Anthropology of Death. Symbols and Rites". We do not know if the papers presented are to be published.

So far we have been concerned with enumerating the gatherings, congresses, and similar events held in those autonomous communities - Madrid, Catalonia, Andalusia, the Canary Islands, Galicia, the Basque Country, and Castile-Léon - where anthropology has reached a certain level of academic institutionalization. In all of them anthropology has at least some place on university curricula. But even in those communities where the process of academic institutionalization is less advanced, or has not got off the ground, interest in anthropology, and even more so in folklore, has given rise to a fair number of scholarly meetings, many of which, as we shall see, have warranted the publication of volumes of acts.

First place, in this respect, undoubtedly goes to Aragon. It was at the instigation of the Institución Fernando el Católico in Saragossa that "National Congresses of Ethnology and Popular Traditions" (Congresos Nacionales de Etnología y Tradiciones Populares) were held in various Spanish cities ${ }^{26}$ and 
the resolutions were published by the Institute itself under the generic title of Etnologia y Tradiciones Populares in 1969, 1974, and 1977 (another volume, for which we have no specific reference, has appeared more recently). The acts of the first "Aragonese Congress of Ethnology and Anthropology" (I Congreso de Aragón de Etnología y Antropologia), held in 1979, were published in 1984, while another volume on the ethnology and folklore of Aragon, entitled Estado actual de los Estudios sobre Aragón, which arose from the fifth "Study Days" (V Jornadas de Estudio) organized by the ICE in Saragossa in 1982, came out in 1984. We have news of two gatherings which took place in Huesca in 1984 and 1985 -the first and second "Autonomous Communities Ethnological Film Contest" ( $I$ and II Certamen de Cine Etnológico de las Comunidades Autónomas) - under the auspices of the Instituto Aragonés de Antropología with the support of the Diputación General de Aragón. The announcement of a third contest in 1986 confirms that this highly specialized event is to continue.

The example of Aragon, a community where anthropological studies are not institutionalized in any way but which produces an abundance of ethnological literature, is not unique in Spain. Since the 1980 s quite a number of groups of local researchers, many of them with support from their autonomous governments, have organized conferences and gatherings on the ethnography and folklore of their respective regions. Such events are beginning to generate an abundant crop of publications, as is proved by the following list which in no way claims to be exhaustive: Cultura tradicional y folklore (cf. Luna Samperio, Coor. 1981, which includes the papers presented at the first Encuentro in Murcia); the Acts of the I Jornadas de Estudio del Folklore Castellano-Manchego (Cuenca, 1983), of the II Jornadas de Etnología de Castilla-La Mancha (Ciudad Real, 1985), of the I Jornadas de Antropología y Folklore Extremeño (cf. Marcos Arévalo, Comp. E.p.), of the II Jornadas de Estudio del Folklore (La Rioja, 1983) etc. ${ }^{27}$. A large number of additional references are given in footnote ${ }^{28}$.

To round off the list, we must refer to the Balearic Islands, another community where studies in cultural and/or social anthropology do not formally exist but where there is considerable awareness of the topic as is shown by the organization of a symposium on oral sources (Col-loqui sobre "Les Fonts Orals", Palma de Mallorca, 1984). Another clear indication of the interest in anthropology to which we have just alluded lies in the publication of the proceedings of the third "Conference on Local Historical Studies" (III Jornades d'Estudis Històrics Locals, cf. La vida quotidiana dins la perspectiva bistòrica, 1985).

Thus far we have given a brief account of publications arising directly from congresses, symposiums, conferences, contests, meetings and so on. Considered jointly, these events represent different forms of collective organization and professional mobilization. Moreover they have become public forums, held at varying intervals, in which the scientific, professional 
and disciplinary interests of the different organizing groups are expressed with relative clarity. Thus we come back to the point made at the begininning of this section: the evolution of the latest topics of interest to anthropologists and how they are reflected in the acts of congresses.

The evolution of these interests can be seen quite clearly, for instance, if we compare the five editions of the Congress of Anthropology $(1973,1974,1977,1981$ and 1984) held so far. One need only examine a set of fairly significant indicators (congress organizers, titles of symposiums and/or study sessions, the prologues or speeches by the chairman which appear at the beginning of the published acts, professional strategies outlined in the resolutions or conclusions, and so on) to notice the far-reaching changes that have taken place in a period of only eleven years ${ }^{29}$. These changes, moreover, some of which are only apparent if one reads between the lines, affect not only theory, methodology and strategy, but the overall conception of what anthropology is, or ought to be, in Spain.

If we turn our attention from the state-wide congresses to those of national or regional scope, the very titles of the gatherings are indicative of another level of concern. Let us recap on some of those already mentioned: $I$ Congreso de Aragón de Etnología y Antropología (1979), II Jornadas de Estudios sobre la Provincia de Madrid (1980), subtitled "Madrid en busca de su identidad" ("Madrid in search of its identity"); I y II Coloquio de Antropoloxia de Galicia, the 1984 edition of which is devoted to the study of "Antropologia y crisis de la sociedad tradicional" ("Anthropology and the crisis of traditional society"); and I Encuentro de Antropólogos held in Jerez de la Frontera (1982) and subtitled "La Antropología cultural en la Andalucía de Hoy" ("Cultural Anthropology in present-day Andalusia"); Jornadas de Antropología Social de Castilla-León (1982); I Congreso de Etnología y Folklore en CastillaLeón (1985), I Jornadas de Antropologia de Madrid (1985), not to mention the already numerous gatherings on folklore, ethnography or ethnology which have taken place in Murcia, Castilla-La Mancha, Extremadura, La Rioja and other parts of Spain. In all the gatherings listed, the stress is on the study of the autonomous communities themselves, since most of the contributions (with the possible exception of those by anthropologists from elsewhere who have usually been specially invited for the occasion) focus on problems deriving from their own cultural particularity. In these cases also, the publication of the proceedings enables one to make an overall assessment of the situation of the discipline and the professional level attained by specialists in the various autonomous communities. The interests of professionals in these communities - subject areas, and theoretical, methodological and strategical aspects - can thus be described with the same accuracy as in the case of the acts of state-wide congresses.

A third type of conference or workshop which appears in the sample is made up of gatherings of specialists interested in particular topics. The generic subject of popular culture seems to have been an extremely attrac- 
tive one for monographic gatherings (cf. Col-loqui sobre l'Estudi de la Cultura Popular, 1981; Culturas Populares. Diferencias, divergencias, conflictos, 1982), as is that of traditional culture, (cf. Luna Samperio, Coor: Cultura tradicional y folklore, 1981; Congrés de Cultura Tradicional i Popular, 1981-1982; II Encuentros Internacionales de Cultura Tradicional, 1986). Both subjects have also formed the basis of numerous congresses devoted to the discussion and study of ethnology, folklore and popular traditions throughout Spain or in particular autonomous communities, as we have already seen. Symposiums or gatherings on more highly specialized topics have been devoted to field work (El trabajo de campo en Antropología, Madrid, 1982, unpublished), the anthropology of medicine (cf. I Jornadas de Antropología de la Medicina, 1982), the ethnography and anthropology of fishing (Coloquio de etnografia maritima, 1984); and to a wide variety of other subjects ranging from oral sources (Palma de Mallorca, 1984) to the ethnohistory of everyday life (La vida quotidiana dins la perspectiva bistòrica, 1985), bullfighting (Los toros desde la antropologia: el sexo, la muerte y lo sagrado en la fiesta de los toros. Sitges. 1985), or the anthropology of country life (Antropologia de les societats pageses. Maó, December 1985)...

Close examination of the question of monographic publications and those specializing in a single subject reveals that a new set of general sources, closely related to all we have been saying so far, needs to be added: published readings, seminars and cycles of lectures.

\section{Readings, seminars and cycles of lectures.}

Chronologically speaking, the first collections of readings to include information on Spain were put together and published by foreign anthropologists who, from the 1960 s onwards, concerned themselves with the study of the Mediterranean. Some of these titles have become classics: the collections by Peristiany (Honour and Shame. The Values of Mediterranean Sociology, 1968; Mediterranean Society, 1965; Contributions to Mediterranean Sociology, 1968; Mediterranean Family Structures, 1967) or by Pitt-Rivers (Mediterranean Countrymen. Essays in the Social Antbropology of the Mediterranean, 1963). The publication of works of this type seemed to have ceased ten years ago until evidence to the contrary was provided by the recent appearance of books by Davis (Religious Organization and Religious Experience, 1982), Kenny and Kertzer (Urban Anthropology in the Mediterranean,1983), and Wolf (Religion, Power and Protest in Local Communities, 1984), all of which focus on the Mediterranean area. D. Gilmore, moreover, has prepared a new volume on the theme of honour and shame (Honour and Shame in the Mediterranean) and a work edited jointly by Peristiany and Pitt-Rivers dealing with the relationship between honour and the sacred is expected to come out soon ${ }^{30}$.

While several authors (and editors) have concentrated on the concept of 
the Mediterranean, as we have just seen, another group chose to highlight the wider geographical context of Europe. Thus, from the 1970s onwards, contributions on Spain are also to be found in a large number of readings on various subjects related to Europe. These include works by $\mathrm{O}$. Pi-Sunyer (The Limits of Integration. Ethnicity and Nationalism in Modern Europe, 1971), Foster (Nations without States: Ethnic Minorities in Europe. 1983) and a long list of other works ${ }^{31}$ including the collections by Weibust (1973), Barberis (1976), and Duran, Drouhin and Swengrub (1981).

Fewer collections of readings have been published by foreign anthropologists on Spain itself. One of the best known is The Changing Faces of Rural Spain (cf. Aceves and Douglass. Eds. 1976), which came out the same year as another similar work entitled Economic Transformation and Steady-State Values. Essays on the Ethnography of Spain (cf. Aceves, Hansen,Levitas. Eds. 1976). The collection of readings by J. Lacroix, Turismo y desarrollo regional en Andalucia (1983), to which we have not had direct access, also deals with the subject of economic change. Two other North American anthropologists - Gary Mc Donogh and James W. Fernández - have prepared their own readings: Mc Donogh's, entitled Conflict in Catalonia: Images of Urban Society, is about to appear, while La Casa en España (provisional title) by James W. Fernández will not be available, it seems, for some time.

During the past six years a growing number of collective works have been published. Many of these new collections are edited by Spaniards and the subjects vary widely as the following titles reveal: La Antropología médica en España (cf. Kenny and de Miguel. Eds. 1980), Antropología y racionalidad (1980), Análisis de la situación de la educación en Sevilla (cf. Jiménez Núnez. Ed. 1981), La pesca en Canarias (1982), Tres escritos introductorios al estudio del parentesco (1983), Sobre agricultores y campesinos (cf. Sevilla Guzmán. Coor. 1984), La Religión en Andalucia. Aproximación a la religiosidad popular (cf. Castón et al., 1985), and so on.

In the prologues to some of these works, the editors, coordinators or directors themselves explain the reasons or basic circumstances that have made the publication of their readings possible. Often they are the fruit of such factors as joint research, team work, or monographic seminars. Hence the need to introduce a new subgroup of publications: those derived from cycles of lectures and seminars, which, as we are about to see, add considerably to the number of collective editions.

The first cycle of lectures was organized by the Asociación Madrileña de Antropología on the subject of "La fiesta" ("festivals"). The book came out two years later under the title Tiempo de fiesta. Ensayos antropológicos sobre las fiestas en España (cf. Velasco. Ed. 1982). This was followed by the publication of a cycle of lectures on "anthropology and health" (cf. Antropologia $i$ Salut, Comelles. Comp. 1984), another entitled Sobre el concepto de cultura (1984), held at the Department of Cultural Anthropology at Lleida, and one on popular culture organized by the Institut Català d'Antropologia (cf. Llo- 
part, Prat, Prats, Eds. 1985. La cultura popular a debat). On other occasions it was internal working seminars which led to the publication of collective works, as in the case of Mujer vasca, imagen y realidad (cf. Del Valle, Dir. 1985), or the work by Angel Aguirre mentioned earlier (Ibid. Dir. 1986. La Antropología Cultural en España) ${ }^{32}$.

In a very similar vein are the published lectures that have formed part of various summer courses in anthropology that have taken place, notably at the Universidad Internacional Menéndez Pelayo. At least two publications - Literatura Oral en América, a monographic issue of Etbnica (18, second part), prepared by Manuel Gutiérrez, and the book El mito ante la antropología y la bistoria (cf. Alcina. Comp. 1984) - are the fruit of such courses held at the UIMP. A third course, which took place in Segovia in 1986 under the title Naturaleza y Cultura: Antropología de la Alimentación en América Latina, is forthcoming. We are not yet sure, moreover, whether the monographic courses held in Andalusia on the subject of festivals (Fiestas, 1983) and ethnicity (Etnicidad, 1984) will be published or not. The published edition of the II Curso Internacional de Cultura Española, coordinated by Julio Alvar, which took place at Caspe in the summer of 1985 , is also forthcoming.

The last subcategory of collective books to which we must refer is made up of studies commissioned by, or conducted under contract to various institutions. Examples are titles like: Los gitanos al Encuentro de la Ciudad (cf. Equipo Giems, 1975), Escuelas, Pueblos y Barrios (cf. Knipmeyer et al., 1980), Guia de Fiestas Populares de Andalucia, directed by Salvador Rodríguez Becerra (1982), and the two volumes entitled Temes d'Etnografia Valenciana, from the series directed by J.F. Mira (1983-1985) in which further works are to appear in due course. Finally, certain eminently editorial works may be seen as a variant of these "commissioned" works: those, for instance, by R. Valdés (Las Razas Humanas, 1982), M. Izard (Marginados, fronterizos, rebeldes y oprimidos, 1985) or J. Frigolé (Las Razas Humanas, 1986), as well as others such as La antropología boy. Una introducción a la antropología cultural (1983) or the monographic volumes on traditions and legends (Tradicions $i$ Llegendes, Dolça Catalunya, 1982, vol. XV and XVI). This last title brings us finally to the numerous publications of a regional or encyclopedic nature and the many popular treatises by anthropologists, upon which however we will refrain from commenting since they go well beyond the scope of our study.

\section{E. Specialized Journals.}

In the foregoing pages we referred to the sources of information we found most meaningful in compiling Thirty Years of Anthropological Literature about Spain. The general picture, however, would in our view not be quite complete without a reference, however brief, to one final source: spe- 
cialized and professional journals. In all scientific communities such journals play an important part in the dissemination, expression and discussion of subjects of scientific and theoretical interest among groups of professionals and in Spanish cultural and social anthropology they have played this same role, becoming organs of expression and a means towards institutionalization of the discipline and the profession.

The veteran journal of modern Spanish anthropology is Ethnica. Revista de Antropologia founded in 1971 by Claudi Esteva in the context of the CSIC's Centro de Etnología Peninsular in Barcelona. The nineteen issues of Ethnica published so far have contained a large number of articles by Spanish and foreign cultural and social anthropologists, as well as by physical and biological anthropologists, prehistorians, ethnohistorians and ethnolinguists, in accordance with the holistic conception of cultural anthropology that its founder and director has always maintained. Latterly Ethnica has been tending to bring out monographic issues.

A few months before the publication of the first volume of Ethnica, Cuadernos de Antropología Social y Etnología (1970-1974?) had been founded by Juan Vicente Palerm in Madrid. This journal, which was put together by rudimentary means, was published by the Department of Anthropology and Ethnology of America with students in mind. After only a few issues (four or five), Cuadernos de Antropologia Social y Etnología ceased publication. Another journal founded in the 70s was Anthropologica. It was devoted to philosophical anthropology and four volumes came out during the first period (1973-1977). Following the public presentation of the Instituto de Antropología de Barcelona in 1982, Anthropológica became the mouthpiece of the members of the Institute and a single monographic issue was published in 1982. After several years' silence, Anthropológica is about to reappear, this time as a publication specializing in the anthropology of medicine ${ }^{33}$.

In 1980, some ten years after the appearance of Ethnica, the members of the Institut Català d'Antropologia (founded in 1978) launched a new professional journal under the title Quaderns de l'Institut Catala d'Antropologia. As its name suggests, Quaderns has been the organ whereby the members and associates of this professional group have expressed their intellectual preoccupations and, above all, reported on individual and, to a lesser extent, collective research. Between 1980 and 1985, Quaderns published five issues, and number six is about to come out.

Since 1981 the staff, graduates and collaborators of the Department of Cultural Anthropology at the Universitat Central de Barcelona have been publishing a new journal entitled Comentaris d'Antropologia Cultural. The object, initially, was to report on their own research projects. After a series of changes in its external format, however, Comentaris has become the third professional journal published in Barcelona. Six volumes have come out so far, one of them monographic.

1982 was undeniably an important year for the creation of new journats 
of anthropology. Four new periodicals were added to those already in existence: Alcaveras (Madrid), Temas de Antropología Aragonesa (Huesca and Saragossa), Gazeta de Antropologia (Granada) and Arxiu d'Etnografia de Catalunya (Tarragona).

The first - Alcaveras. Revista de Antropología (1982-1986) - was originally the Gaceta de la Asociación Madrileña de Antropologia. From the third issue onwards it took on a more professional style while maintaining its primary objective of encouraging publications by and intellectual discussion among members of the AMA. For the first five issues, Alcaveras was a cross between a professional bulletin and a genuine journal. At the end of this period it began to lean distinctly towards the latter option ${ }^{34}$.

Temas de Antropologia Aragonesa (1982-1986), three issues of which have come into our hands, is the official organ of the Instituto Aragonés de Antropología, an organization grouping specialists in the study of ethnology and anthropology in Aragon. In 1985, the members of the IAA launched a "Monographic series" in which two works of an ethnographical nature have so far been published ${ }^{35}$.

The third journal founded in 1982 was the Gazeta de Antropologia attached to the Asociación Granadina de Antropología. The prime objectives defined in the presentation included such things as the stimulation of ethnological and anthropological studies on the Andalusian cultural area and the encouragement of scientific exchange. The small group of professionals from Granada who support the Gazeta de Antropologia have so far brought out four issues.

Arxiu d'Etnografia de Catalunya (1982-1986) is the fourth professional publication mentioned above and the last to appear in the field that concerns us. Arxiu d'Etnografia de Catalunya was founded at the Department of Anthropology at Tarragona as one of several means designed to encourage team research in the department. The present study constitutes the fourth volume to be published so $\mathrm{far}^{36}$.

In the above brief outline we referred to anthropological journals in the narrow sense of the term. As in the case of other sources of general information (especially the acts of congresses), we feel it may be worthwhile to supplement our account by alluding to other types of publications which, though they cannot properly be considered anthropological journals, have given ample proof of their dedication and sensitivity towards the neighbouring fields of ethnology, ethnography, folklore and popular traditions and customs. Moreover, as will be seen from the bibliography, it is through these journals that a large number of works signed by professional anthropologists have appeared in print ${ }^{37}$.

Among these publications, it is undoubtedly the Revista de Dialectologia y Tradiciones Populares that enjoys most prestige. Founded in 1944 by V. García de Diego and published by the CSIC's Instituto "Miguel de Cervantes", it has continued regular publication right up to the present day. In 
1983 a volume entitled Indices de la Revista de Dialectología y Tradiciones Populares (Tomos $I-X X X V$ ) came out. This includes a carefully compiled list of authors and subjects as well as a geographical index and another of the works reviewed. The list spans the period from 1944, the year the journal was founded, to 1980, and its usefulness in ascertaining the RDTP's broad lines of interest need hardly be stressed.

While on the subject of publications from Madrid, we must mention two more: Narria (1967-86) and Etnografía Española (1980-1986). The former, subtitled Estudios de Arte y Costumbres Populares, is run by the Museo de Arte y Tradiciones Populares which is attached to the Department of Prehistory and Archeology of the Universidad Autónoma de Madrid. Narria, which is published every four months, brings out mostly monographic issues devoted to the different Spanish provinces.

The second of these journals -Etnografía Española - was founded in 1980 by the Ministry of Culture's Department of Archeology. An annual volume of miscellanea is published. Another well-established publication, in this case from the autonomous community of Castile-León, is the Revista de Folklore published in Valladolid by the Obra Cultural de la Caja de Ahorros Provincial de Valladolid. This collection has brought out over sixty issues. The autonomous community of Castile-La Mancha also possesses two journals with a pronounced interest in subjects relating to folklore and ethnography: Wad-al-Hayara (1974-1986), published by the Institución Provincial de Cultura Marqués de Santillana in Guadalajara, and Albasit, founded in 1975, which is presently attached to the Instituto de Estudios Albacetenses (IEA). The list of similar journals which, though not specializing in ethnography, have devoted numerous pages to the diffusion of studies on folklore and traditional culture can be extended to include the remaining autonomous communities of Spain. Significant examples are: Revista de Estudios Extremeños ${ }^{38}$ (1927-1986. Diputación Provincial de Badajoz); Berceo (1946-1986. Instituto de Estudios Riojanos); Cuadernos del Instituto de Etnología y Folklore Hoyos Sainz (Ibid. Diputación Provincial de Santander); Cuadernos de Estudios Gallegos (Instituto Padre Sarmiento de Estudios Gallegos, Santiago) ; Grial. Revista Galega de Cultura (Editorial Galaxia, Vigo), LLuc (1968-1986. Obra Cultural Balear); Quaderns de Folklore (1979-1986. Col-lectiu Folklòric de Ciutadella. Minorca); Pirineos (over 100 issues published. Centro Pirenaico de Biología Experimental. Jaca); Kalatbos. Serie Etnológica (Seminario de Arqueología y Etnología Turolense, Colegio Universitario de Teruel); Teruel (Instituto de Estudios Turolenses, including a section on cultural anthropology), and many more.

We have quite deliberately left the journals from the Basque Country and Navarre for the end, since these communities have probably the most complete network of publications specialized in ethnology, ethnography and folklore in the whole of Spain.

The first journal to commence publication after the Civil War was 
Anuario de Eusko-Folklore (1955. Second period). It was commissioned by the Sociedad de Ciencias Aranzadi in San Sabastian to José Miguel de Barandiarán, who had recently returned from exile. Some years later (1964), Barandiarán was to occupy the chair of Basque culture at the University of Navarre and it was under his leadership that, in 1975, the foundation of the Etniker groups, devoted to ethnic research, and their respective journals, got underway. The Etniker group journals corresponding to each of the Basque provinces are; Anuario de Eusko-Folklore (the mouthpiece of Eusko Ikaskuntza/Sociedad de Estudios Vascos in Guipúzcoa), Obitura. Estudios de Etnografía Alavesa (published by the Seminario de Etnografía de la Diputación Foral in Alava), and Etniker-Biscaia (the organ of the Department of Ethnography at the Instituto Labayru in Bilbao, Vizcaya).

The Sociedad de Estudios Vascos in San Sebastian commenced publication of Cuadernos de Antropologia y Etnografia, while the Institución Príncipe de Viana in Pamplona, founded in 1940, launched Cuadernos de Antropologia y Etnografia de Navarra (1969-1986). The last members of this extensive network of publications are Kobie (ethnography) and Cuadernos de Toponimia, published by the Diputación Foral de Vizcaya and the Seminario Alavés de Etnografía respectively. 